\title{
PENGARUH TEKANAN (PRESSURE), KESEMPATAN (OPPORTUNITY), RASIONALISASI (RATIONALIZATION), DAN KAPABILITAS (CAPABILITY) TERHADAP KECURANGAN PENGADAAN BARANG/JASA DI PEMERINTAHAN ACEH DENGAN PEMODERASI BUDAYA ETIS ORGANISASI
}

\author{
Finalia Fitri*1 ${ }^{1}$ Nadirsyah $^{* 2}$ \\ ${ }^{1,2}$ Program Studi Akuntansi Fakultas Ekonomi dan Bisnis Universitas Syiah Kuala \\ e-mail: finalia_fitri@yahoo.com ${ }^{* 1}$, nadirsyah@unsyiah.ac.id ${ }^{* 2}$
}

\begin{abstract}
This study has purposes to discover whether pressure, opportunity, rationalization and capability influences towards fraud of procurement goods and services in Aceh Government with ethic cultural organization as a moderator. Testing was conducted to 20 SKPD in Aceh Government which arranged an event of procurement goods and services. This study uses primary data of questioner which was distributed to all 60 respondents that consist of Head of minister, Firma, Institute, Secretary, and Head of finance, the sample of study is taken by purposive sampling. Testing is conducted by using moderated analyzing Regression (MRA). The result of study shows that partially pressure and capability influences towards fraud of procurements good and service, meanwhile opportunity, rationalization, and ethic cultural organization were not influenced towards fraud of procurements goods and services. In testing of moderate regression analyzing uses interaction test, partially ethic cultural organize is able to moderate the relationship between opportunity and rationalization towards fraud of procurement. But, ethic cultural organization is not able to moderate the relationship between pressure and capability towards fraud of procurement goods and services.
\end{abstract}

Keywords: Fraud of procurement goods and services, pressure, opportunity, rationalization, capability, and Ethic cultural organization

\section{Pendahuluan}

Korupsi menjadi suatu permasalahan besar yang melekat di Indonesia, kontinuitas permasalahan tersebut menjadikan korupsi sebagai salah satu akar permasalahan yang menghambat kesejahteraan masyarakat. Setiap tahun Komisi Pemberantasan Korupsi (KPK) selalu menemukan kasus-kasus baru yang mengakibatkan kerugian negara dalam jumlah besar. Padahal telah banyak upaya yang dilakukan untuk memberantas korupsi, namun tetap saja permasalahan tersebut terus terjadi tanpa kenal henti.

Hal ini dapat dibuktikan dengan melihat kasus korupsi berdasarkan jenis perkara urutan lima besar (top five) kasus korupsi yang paling dominan terjadi di Indonesia dari tahun 2004-2018 ialah penyuapan, pengadaan barang/jasa, penyalahgunaan anggaran, pungutan, dan perizinan. Selama 14 tahun kasus penyuapan terus konsisten menempati posisi pertama sebagai korupsi yang paling sering terjadi dengan akumulasi jumlah kasus sebanyak 564 kasus. Kemudian di posisi kedua ditempati oleh kasus korupsi di sektor pengadaan barang dan jasa dengan jumlah kasus sebanyak 188 kasus. Posisi ketiga, keempat dan kelima masing-masing ditempati oleh penyalahgunaan anggaran, pungutan, dan perizinan dengan jumlah kasus secara berturut-turut sebanyak 46, 25 dan 23 kasus (kpk.go.id).

Dari segi nilai kerugian, perbandingan jumlah kerugian kasus korupsi secara keseluruhan tahun 2016 dan 2017, sebesar Rp1,45 triliun nilai kerugian harus ditanggung oleh negara akibat terjadinya kasus korupsi sebanyak 482 kasus di tahun 2016. Sedangkan untuk tahun 2017, jumlah kerugian negara meningkat pesat menjadi Rp6,56 triliun yang menjadi akibat dari terjadinya 576 kasus korupsi di tahun 2017 (kpk.go.id). Salah satu kasus korupsi yang mengakibatkan terjadinya lonjakan kerugian tersebut ialah adanya pengusutan terhadap kasus korupsi di sektor pengadaan barang/jasa yaitu kasus korupsi pengadaan Kartu Tanda Penduduk Elektronik (EKTP). Ini merupakan salah satu dari banyaknya bentuk kasus korupsi pengadaan barang dan jasa yang terjadi 
di Indonesia, pernyataan ini sesuai dengan pendapat yang diutarakan oleh Basaria Panjaitan selaku Wakil ketua Komisi Pemberantasan Korupsi yang mengatakan bahwa titik rawan terjadinya tindak pidana korupsi ialah pada bidang pengadaan barang dan jasa ("Korupsi Pengadaan Barang," 2017).

Korupsi pengadaan barang/jasa merupakan salah satu bentuk kecurangan yang dilatarbelakangi oleh berbagai faktor. Faktor-faktor tersebut bersumber dari teori segitiga kecurangan (triangle fraud) yang dikembangkan oleh Cressey (1953) yang terdiri dari tekanan, kesempatan dan rasionalisasi. Lalu, pada tahun 2004 teori ini disempurnakan oleh Wolfe \& Hermanson (2004) dengan teori segiempat kecurangan (diamond fraud), yang terdiri dari tekanan, kesempatan, rasionalisasi dan kapabilitas.

Tekanan (pressure) merupakan faktor pertama yang dapat mendorong seseorang atau kelompok untuk melakukan tindakan kecurangan. Tekanan yang dialami seseorang seperti tekanan finansial dan nonfinansial menyebabkan seseorang berada pada kondisi sulit dan terjepit sehingga berusaha melakukan segala cara untuk terbebas dari kondisi tersebut (Farida, 2017). Selain itu, tekanan organisasi yang selalu menuntut kinerja pegawai agar sesuai dengan target juga memberikan andil besar dalam memicu seseorang melakukan aktivitas kecurangan (Mustikasari, 2013).

Kesempatan (opportunity) merupakan faktor kedua yang mempengaruhi seseorang untuk berbuat curang, yang dapat didefinisikan sebagai situasi seseorang disertai dengan keadaan yang memungkinkannya untuk melakukan tindakan kecurangan tanpa diketahui oleh orang lain. Kesempatan sering dikaitkan dengan sistem pengendalian internal, semakin tidak efektif sistem pengendalian internal yang diterapkan maka semakin meningkat kesempatan yang tersedia untuk melakukan aktivitas kecurangan (Albrecht et al., 2012).

Rasionalisasi (rationalization) menjadi faktor ketiga yang mendukung seseorang atau kelompok untuk melakukan kecurangan. Rasionalisasi merupakan bentuk pembenaran diri pelaku atas apa yang telah dilakukannya. Rasionalisasi dilakukan untuk membenarkan tindakan yang telah dilakukan, meskipun ada pihak lain yang merasa dirugikan (Molida, 2011).

Kapabilitas (capability) menjadi faktor keempat yang didefinisikan sebagai kemampuan seseorang dan berperan besar dalam melakukan kecurangan. Keberhasilan seseorang dalam melaksanakan kecurangan ditentukan oleh kemampuan yang dimilikinya seperti posisi/jabatan, kecerdasan, keegoisan, sifat persuasif, kebohongan, dan pengendalian stress (Wolfe \& Hermanson, 2004).

Selain keempat faktor yang telah dijelaskan tersebut, faktor lain yang berpengaruh terhadap kecurangan ialah budaya etis organisasi. Sawitri (2011) menyatakan bahwa budaya etis organisasi adalah cara pandang yang dimiliki oleh anggota organisasi dan diterapkan secara bersama-sama di suatu sistem organisasi. Budaya etis organisasi mempunyai peranan yang dapat menurunkan intensitas kecurangan dan bahkan dapat meningkatkan intensitas kecurangan. Semua itu bergantung pada budaya yang dimiliki oleh suatu organisasi.

Berdasarkan uraian fenomena dan latar belakang yang telah dipaparkan, maka penulis tertarik untuk melakukan penelitian dengan judul "Pengaruh Tekanan (Pressure), Kesempatan (Opportunity), Rasionalisasi (Rationalization), dan Kapabilitas (Capability) Terhadap Kecurangan Pengadaan Barang/Jasa di Pemerintahan Aceh dengan Pemoderasi Budaya Etis Organisasi”.

\section{Kerangka Teoritis Dan Pengembangan Hipotesis}

\section{Kecurangan Pengadaan Barang/Jasa}

Menurut Nugroho et al., (2015) Kecurangan pengadaan barang/jasa di pemerintahan dapat dikategorikan sebagai berikut:

1) Barang/jasa tidak sesuai dengan yang dibutuhkan oleh masyarakat dari aspek jenis, kualitas dan kuantitas.

2) Adanya perbedaan spesifikasi barang/jasa yang sudah ditetapkan dalam kontrak perjanjian dengan pekerjaan yang telah diselesaikan.

3) Kuantitas (volume) barang tidak sama dengan jumlah barang yang telah disepakati dalam kontrak.

4) Adanya unsur mark-up yang berakibat pada naiknya harga barang/jasa yang tidak sesuai dengan harga pasar.

5) Pekerjaan barang/jasa tidak selesai tepat waktu dan tidak sesuai dengan kontrak perjanjian. 


\section{Tekanan (Pressure)}

Menurut Rasha \& Andrew (2012) tekanan yang memicu seseorang untuk melakukan kecurangan dapat bersumber dari berbagai hal seperti tekanan pribadi seseorang, tekanan pekerjaan dan tekanan eksternal. Sedangkan menurut Skousen et al., (2008) ada empat kondisi umum yang menyebabkan seseorang melakukan perbuatan curang, diantaranya:

1) Financial stability pressure, ialah tekanan yang berhubungan dengan kestabilan kondisi keuangan suatu organisasi.

2) Financial target, ialah tekanan yang mengharuskan para pegawai/karyawan untuk bekerja sesuai dengan target atau bahkan melebihi target yang telah ditetapkan.

3) Personal financial need, ialah tekanan yang berhubungan dengan tingkat kebutuhan keuangan seseorang secara personal dalam rangka pemenuhan kebutuhan hidupnya.

4) External pressure, tekanan yang bersumber dari pihak luar atau pihak ketiga seperti kreditor, investor dan regulator.

\section{Kesempatan (Opportunity)}

Kesempatan adalah peluang yang dimiliki oleh setiap individu untuk melakukan tindakan kecurangan, dengan kata lain seseorang memanfaatkan kesempatan yang ada untuk memperoleh keuntungan pribadi (Widarti, 2015). Kesempatan juga sering dikaitkan dengan penerapan sistem pengendalian internal, bahwa kesempatan meningkat ketika pengendalian internal yang diimplementasikan di suatu organisasi kurang baik dan efektif, sehingga dapat disalahgunakan. Selain itu, tidak adanya pemisahan tugas dan wewenang dalam suatu jabatan juga dapat memberikan peluang untuk dimanfaatkan oleh pelaku yang tidak bertanggungjawab (Sihombing \& Rahardjo, 2014).

\section{Rasionalisasi (Rationalization)}

Menurut Annisya et al., (2016) rasionalisasi adalah perilaku yang menolerir atau memperbolehkan individu melakukan kecurangan dan berasumsi bahwa tindakan tersebut hal yang biasa dan wajar. Rasionalisasi juga didefinisikan sebagai bentuk sikap dan proses berfikir yang didasari dengan berbagai pertimbangan moral individu karyawan untuk merasionalkan perilaku kecurangan dengan menggunakan beragam alasan sebagai bentuk pembenaran atas perilakunya (Apriadi, 2014). Kemudian Ratmono et al., (2014) menyatakan bahwa rasionalisasi berkaitan dengan sikap dan kepribadian seseorang dalam membenarkan nilai-nilai etis yang sebenarnya menyimpang.

\section{Kapabilitas (Capability)}

Kapabilitas dapat menjadi tolak ukur seberapa besar kemampuan seseorang untuk melakukan tindakan kecurangan di lingkungan kerja, baik di swasta maupun pemerintahan (Wolfe \& Hermanson, 2004). Tingkat kapabilitas seseorang sangat erat kaitannya dengan akibat yang ditimbulkan dari kecurangan. Mengapa demikian, semakin tinggi kapabilitas seseorang dalam menempati posisi jabatan di instansi/perusahaan, maka semakin besar jumlah nominal kerugian yang ditimbulkan. Menyikapi permasalahan tersebut Ristianingsih (2017) mengemukakan ada tiga hal yang dapat menimbulkan perilaku kecurangan, diantaranya:

1) Jabatan di suatu organisasi;

2) Kemampuan untuk memahami pengendalian internal serta berusaha untuk mencari kelemahan dari sistem tersebut;

3) Tingginya rasa kepercayaan diri yang meyakini bahwa tindakannya tidak akan diketahui orang lain.

\section{Budaya Etis Organisasi}

Budaya etis organisasi merupakan persepsi para pegawai terhadap tindakan etis pemimpin mengenai pentingnya mengutamakan etika serta pemberian sanksi kepada tindakan yang menyimpang dan tidak bermoral di dalam organisasi (Hunt \& Vite, 1986). Sejalan dengan pernyataan tersebut, Nurfarida (2011) menyatakan bahwa nilai-nilai yang tumbuh dan tertanam kuat dalam organisasi merupakan inti dari budaya organisasi yang tercermin dari praktik organisasi. Nilai-nilai tersebut dapat menciptakan keefektifan dan memberikan kemudahan kepada anggota organisasi untuk mencapai tujuan yang diharapkan. Namun, apabila nilai ini tidak diimplementasikan dengan tepat akan berakibat kepada semakin tingginya tingkat kecurangan yang terjadi (Kinicki \& Kreitner, 2003). 


\section{Kerangka Pemikiran}

\section{Pengaruh Tekanan (Pressure) Terhadap} Kecurangan Pengadaan Barang/Jasa

Tekanan adalah motivasi yang timbul dari individu pegawai untuk melakukan perbuatan curang dan menyimpang disebabkan karena adanya tekanan, seperti tekanan finansial dan non-finansial (Arifianti et al., 2015). Semakin besar tekanan yang dialami maka semakin kuat motivasinya untuk berbuat kecurangan. Pernyataan tersebut didukung dengan hasil penelitian Zahara (2017) dan Marliani \& Jogi (2015) yang menyatakan bahwa tekanan berpengaruh terhadap kecurangan.

\section{Pengaruh Kesempatan (Opportunity) Terhadap Kecurangan Pengadaan Barang/Jasa}

Kecurangan yang terjadi pada kegiatan pengadaan barang/jasa disebabkan karena kurangnya pengawasan pada proses pelaksanaan pengadaan barang/jasa pemerintah, minimnya pengawasan dari atasan langsung, serta tingkat kesadaran pelaku yang kurang bahwa tindakan tersebut salah dan dapat menimbulkan konsekuensi hukum. Kurangnya pengawasan tersebut mengakibatkan timbulkan kesempatan yang dapat dimanfaatkan oleh pelaku untuk melakukan aktivitas kecurangan. Hal tersebut dibuktikan dengan penelitian Susandra \& Hartina (2017), Pamungkas (2018), Purwanto et al., (2017) yang menyatakan kesempatan memiliki pengaruh positif dan signifikan terhadap kecurangan pengadaan barang/jasa.

\section{Pengaruh Rasionalisasi (Rationalization) Terhadap Kecurangan Pengadaan Barang/Jasa}

Rasionalisasi merupakan bentuk pembenaran seseorang atas perilaku curang yang dilakukan sehingga merasa tidak bersalah dan tidak menyesali perbuatannya, apabila tingkat rasionalisasi seseorang tinggi maka semakin besar rasa tidak bersalah dalam melakukan kecurangan. Pernyataan ini dibuktikan dengan penelitian Lailiyah (2016) dan Arifianti et al., (2015) yang memperoleh hasil bahwa rasionalisasi berpengaruh terhadap kecurangan.

\section{Pengaruh Kapabilitas (Capability) Terhadap Kecurangan Pengadaan Barang/Jasa}

Purwanto et al., (2017) menjelaskan bahwa untuk melakukan pencegahan dan pengantisipasian terhadap kecurangan pengadaan barang/jasa di pemerintahan belumlah cukup jika hanya berfokus kepada tekanan, kesempatan dan rasionalisasi. Oleh sebab itu, perlu mempertimbangkan kehadiran faktor lain seperti kapabilitas seseorang. Uraian tersebut dijelaskan bukan tanpa bukti, adanya penelitian terdahulu dari Pamungkas (2018), Purwanto et al., (2017) memperoleh hasil bahwa kapabilitas berpengaruh positif terhadap kecurangan (fraud).

\section{Pengaruh Budaya Etis Organisasi Terhadap Kecurangan Pengadaan Barang/Jasa}

Budaya etis yang diterapkan di suatu organisasi merupakan cerminan bagaimana keseluruhan anggota berinteraksi dan bertingkah laku di dalam suatu organisasi (Dewi et al., 2015). Sehingga tercipta lah ciri khas bagi organisasi itu dan memberikan daya tarik yang dapat mengundang orang lain bergabung ke organisasi tersebut (Fachrunisa, 2015). Pernyataan ini diperkuat dengan hasil riset terdahulu dari Fachrunisa (2015) dan Dewi et al., (2015) bahwa budaya etis organisasi berpengaruh terhadap kecurangan di bidang akuntansi.

\section{Pengaruh Budaya Etis Organisasi Terhadap Hubungan Antara Tekanan Dengan Kecurangan Pengadaan Barang/Jasa}

Baik atau buruknya budaya etis organisasi tergantung dari nilai dan norma yang menjadi pedoman bagi suatu organisasi, Apabila nilai dan norma tersebut mengedepankan integritas, tentunya angka kecurangan nihil dan begitu pula sebaliknya. Sama hal nya dengan tekanan semakin beragam tekanan yang dirasakan orang-orang, cenderung memotivasinya untuk melakukan tindakan melawan hukum. Kondisi seperti ini menjadikan budaya etis organisasi sebagai pemoderasi hubungan antara tekanan dengan kecurangan pengadaan barang/jasa.

\section{Pengaruh Budaya Etis Organisasi Terhadap Hubungan Antara Kesempatan Dengan Kecurangan Barang/Jasa}

Tingginya intensitas kecurangan disebabkan karena terbukanya kesempatan/peluang yang dapat disalahgunakan oleh pelaku, hal tersebut menjadi dampak dari adanya sistem pengendalian internal di suatu instansi tidak berjalan dengan baik dan efektif. Baik atau tidaknya suatu sistem pengendalian 
ditentukan oleh organisasi, ini lah yang korelasi antara budaya etis organisasi dengan kesempatan, korelasi tersebut menjadi alasan budaya etis organisasi sebagai pemoderasi terhadap hubungan kesempatan dengan kecurangan pengadaan barang/jasa. Untuk membuktikan pernyataan tersebut, hasil riset Aulad et al., (2018) menunjukkan bahwa hasil uji parameter individual budaya organisasi dapat memoderasi pengaruh partisipasi penyusunan anggaran terhadap kinerja aparat pemerintah daerah Kota Malang..

\section{Pengaruh Budaya Etis Organisasi Terhadap Hubungan Antara Rasionalisasi Dengan Kecurangan Pengadaan Barang/Jasa di Pemerintah.}

Ketika sebagian besar pegawai mempunyai kebiasaan melakukan pembenaran diri atau menganggap bahwa rasionalisasi merupakan hal yang wajar dan lumrah untuk dilakukan maka akan berdampak kepada pola kebiasaan organisasi yang memperbolehkan perbuatan rasionalisasi dalam lingkungan kerja. Pernyataan tersebut sesuai dengan riset Aulad et al., (2018) menunjukkan bahwa secara simultan budaya organisasi berpengaruh terhadap kinerja aparat pemerintah daerah Kota Malang.

\section{Pengaruh Budaya Etis Organisasi Terhadap Hubungan Antara Kapabilitas Dengan Kecurangan Pengadaan Barang/Jasa}

Sawitri (2011) menjelaskan budaya organisasi menjadi kontribusi utama yang menentukan etis atau tidaknya perilaku anggota organisasi. Setiap pegawai yang berada pada suatu organisasi harus tunduk dan patuh terhadap budaya yang sudah ditetapkan oleh organisasi tempat mereka bekerja, sekalipun mereka memiliki kapabilitas yang tinggi serta kompetensi yang bagus. Tidak ada pengecualian bagi pegawai yang tidak mematuhi nilai-nilai etika untuk tidak dikenakan sanksi, pendapat ini diutarakan oleh Hunt \& Vite (1986). Dengan demikian Dengan demikian, budaya etis organisasi dapat menjadi pemoderasi untuk hubungan antara kapabilitas dengan kecurangan pengadaan barang/jasa.

Berdasarkan penjelasan diatas, maka skema kerangka pemikiran dapat digambarkan sebagai berikut:

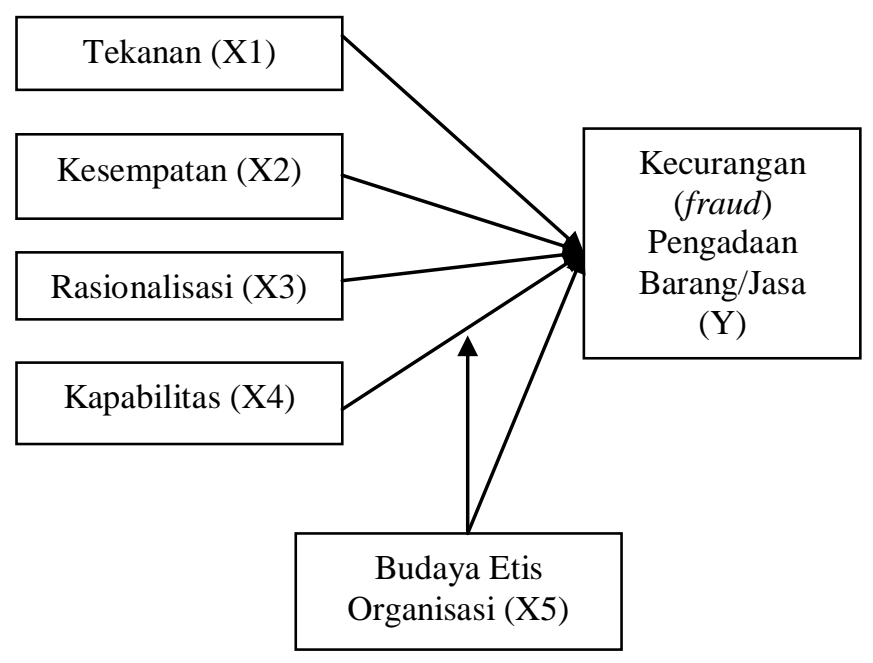

\section{Hipotesis Penelitian}

Berdasarkan teori yang telah dikemukakan sebelumnya, maka dapat dirumuskan beberapa hipotesis penelitian sebagai berikut:

H1: Tekanan (pressure) berpengaruh terhadap kecurangan pada pengadaan barang/jasa Pemerintahan Aceh.

H2: Kesempatan (opportunity) berpengaruh terhadap kecurangan pada pengadaan barang/jasa Pemerintahan Aceh.

H3: Rasionalisasi (rationalization) berpengaruh terhadap kecurangan pada pengadaan barang/jasa Pemerintahan Aceh.

H4: Kapabilitas (capability) berpengaruh terhadap kecurangan pada pengadaan barang/jasa Pemerintahan Aceh.

H5: Budaya etis oganisasi berpengaruh terhadap kecurangan pada pengadaan barang/jasa Pemerintahan Aceh.

H6: Budaya etis organisasi berpengaruh terhadap hubungan antara tekanan dengan kecurangan pengadaan barang/jasa Pemerintahan Aceh.

H7: Budaya etis organisasi berpengaruh terhadap hubungan antara kesempatan dengan kecurangan pengadaan barang/jasa Pemerintahan Aceh.

H8: Budaya etis organisasi berpengaruh terhadap hubungan antara rasionalisasi dengan kecurangan pengadaan barang/jasa Pemerintahan Aceh.

H9: Budaya etis organisasi berpengaruh terhadap hubungan antara kapabilitas dengan kecurangan pengadaan barang/jasa Pemerinta 


\section{Metode Penelitian \\ Desain Penelitian}

Tujuan studi dalam penelitian ini adalah pengujian hipotesis. Jenis investigasi dari penelitian ini bersifat studi kausalitas. Penelitian ini menggunakan data primer berupa kuesioner. Horizon waktu yang digunakan dalam penelitian ini adalah cross sectional.

\section{Populasi Sampel}

Populasi dalam penelitian ini adalah SKPD di Pemerintahan Aceh yang melaksanakan kegiatan pengadaan barang/jasa berjumlah 47 SKPD. Sampel dipilih menggunakan teknik purposive sampling, kriteria pemilihan sampel ialah SKPD yang memiliki jumlah paket pengadaan diatas 80 paket baik secara swakelola maupun penyedia. Sehingga sampel yang dipilih menjadi 23 SKPD, di setiap SKPD akan didistribusikan sebanyak 3 kuesioner yaitu 1 untuk kepala SKPD, 1 untuk kassubag keuangan, dan 1 untuk sekretaris. Total secara keseluruhan berjumlah 69 responden.

\section{Operasional Variabel}

\section{Kecurangan Pengadaan Barang/Jasa}

Kecurangan di sektor pengadaan barang/jasa ialah tindakan menyimpang dan melawan hukum yang dilakukan oleh individu atau kelompok (Tuanakotta, 2013:28). Kecurangan yang dimaksud seperti penggelapan proyek pengadaan, penggelembungan volume barang, melakukan mark-up harga barang, dan lain-lain. Variabel ini terdiri dari 8 item pertanyaan dengan indikator pengukuran yang dikembangkan oleh Mustikasari (2013) dan diukur dengan skala liker 1-5. Indikator yang digunakan yaitu kecurangan laporan keuangan, penyalahgunaan aset dan korupsi.

\section{Tekanan (Pressure)}

Tekanan merupakan motivasi seseorang untuk melakukan aktivitas kecurangan baik dalam hal keuangan maupun non keuangan yang dipengaruhi oleh tekanan internal seseorang dan tekanan organisasi (Mustikasari, 2013). Variabel ini terdiri dari 8 item pertanyaan dengan indikator pengukuran yang dikembangkan oleh Yeni (2011) dan diukur dengan skala liker 1-5. Indikator yang digunakan yaitu tekanan keuangan, kebiasaan buruk, tekanan pekerjaan, dan tuntutan pemenuhan gaya hidup.

\section{Kesempatan (Opportunity)}

Sihombing \& Rahardjo (2014) berpendapat bahwa kesempatan meningkat ketika pengendalian internal yang diimplementasikan di suatu organisasi kurang baik dan efektif, sehingga dapat disalahgunakan. Kesempatan diukur menggunakan instrumen yang telah dikembangkan oleh Sihombing \& Rahardjo (2014) yang terdiri dari 6 item pertanyaan, dan diukur menggunakan skala likert 1-5. Indikator yang digunakan ialah lingkungan pengendalian, aktivitas prosedur pengendalian, embatasan akses informasi, dan ketidakpedulian pimpinan terhadap bawahan.

\section{Rasionalisasi (Rationalization)}

Rasionalisasi adalah pembenaran rasional yang dilakukan pelaku dengan anggapan bahwa tindakan yang dilakukan adalah benar dan wajar, meskipun ada pihak lain yang menjadi korban dan merasa dirugikan (Molida, 2011). Rasionalisasi diukur menggunakan instrumen yang dikembangkan oleh Mustikasari (2013) yang terdiri dari 5 item pertanyaan diukur dengan skala likert 1-5. Indikator yang digunakan diantaranya rela berkorban untuk instansi, tidak ada pihak yang dirugikan, dan tindakan kecurangan dilakukan demi kebaikan.

\section{Kapabilitas (Capability)}

Kapabilitas adalah kemampuan untuk memanfaatkan kesempatan yang ada untuk berbuat curang, yang mana kesempatan tersebut tidak dimiliki oleh orang lain dengan posisi jabatan yang berbeda (Wolfe \& Hermanson, 2004). Kapabilitas diukur dengan instrumen dari Wolfe \& Hermanson (2004) yang terdiri dari 7 item pertanyaan, dan diukur menggunakan skala likert 1-5. Indikator tersebut diantaranya positioning, intelligence, confidencelego, coercion, deceit, dan stress

\section{Budaya Etis Organisasi}

Simbolon (2017) mendefinisikan budaya etis organisasi sebagai nilai, norma, kepercayaan, perilaku, dan tindakan yang menggambarkan bagaimana pihakpihak dalam organisasi berperilaku dan berinteraksi. Pengukuran budaya etis organisasi menggunakan instrumen yang dikembangkan oleh Nurfarida (2011) yang terdiri dari 8 item pertanyaan dan diukur dengan skala likert 1-5. Indikator yang digunakan adalah 
persepsi karyawan pada tindakan etis pimpinan, rasa peduli pimpinan terhadap pentingnya etika di instansi, serta adanya penghargaan untuk tindakan yang bermoral dan sanksi terhadap tindakan menyimpang.

\section{Teknik Pengumpulan Data}

Data primer dikumpulkan melalui penelitian dengan membagikan kuesioner. Setiap kuesioner terdiri dari 1 (satu) variabel terikat, 4 (empat) variabel bebas dan 1 (satu) variabel moderasi.

\section{Metode Penelitian}

Alat analisis yang digunakan dalam penelitian ini adalah analisis regresi moderasi (Moderated Regression Analysis) untuk menguji hipotesis. Alasan penggunaan analisis tersebut ialah adanya variabel moderasi sehingga diperlukan uji interaksi antara variabel bebas dan moderasi. Sehingga model regresi nya adalah sebagai berikut:

$\mathrm{Y}=\mathrm{a}+\mathrm{b} 1 \mathrm{X} 1+\mathrm{b} 2 \mathrm{X} 2+\mathrm{b} 3 \mathrm{X} 3+\mathrm{b} 4 \mathrm{X} 4+\mathrm{b} 5 \mathrm{X} 5+$

$b 6 X 1 X 5+b 7 X 2 X 5+b 8 X 3 X 5+b 9 X 4 X 5+e$

Keterangan:

$$
\begin{aligned}
& \mathrm{Y}=\text { Kecurangan }(\text { fraud }) \text { Pengadaan Barang/Jasa } \\
& \mathrm{a}=\text { Konstanta } \\
& \mathrm{b}=\text { Koefisien Regresi } \\
& \mathrm{X} 1=\text { Tekanan (Pressure) } \\
& \mathrm{X} 2=\text { Kesempatan (Opportunity) } \\
& \mathrm{X} 3=\text { Rasionalisasi (Rationalization) } \\
& \mathrm{X} 4=\text { Kapabilitas (Capability) } \\
& \mathrm{X} 5=\text { Budaya Etis Organisasi } \\
& \mathrm{e} \quad=\text { Error }
\end{aligned}
$$

Pengelolaan data dilakukan menggunakan program SPSS versi 21.0, dengan tingkat signifikansi $5 \%$.

\section{Hasil Dan Pembahasan \\ Deskripsi dan Analisis Data}

Penelitian ini dilakukan dengan mendistribusikan kuesioner kepada kepala/pimpinan, sekretaris, dan Kassubag di setiap Satuan Kerja Perangkat Daerah (SKPD) di Pemerintahan Aceh yang terlibat dalam kegiatan pengadaan barang/jasa yang berjumlah 69 responden dan tersebar di 23 SKPD. Dari 69 kuesioner yang dibagikan kepada responden, kuesioner yang kembali berjumlah 60 atau sebanyak $87 \%$ dan yang tidak kembali sebanyak 9 atau $13 \%$.

\section{Uji Kualitas Data}

\section{Hasil Uji Validitas}

\begin{tabular}{|c|c|c|c|c|}
\hline Variabel & Item & r-hitung & r-tabel & Ket \\
\hline \multirow{8}{*}{$\begin{array}{c}\text { Tekanan } \\
\text { (X1) }\end{array}$} & 1 & 0,668 & 0,254 & Valid \\
\hline & 2 & 0,776 & 0,254 & Valid \\
\hline & 3 & 0,359 & 0,254 & Valid \\
\hline & 4 & 0,467 & 0,254 & Valid \\
\hline & 5 & 0,355 & 0,254 & Valid \\
\hline & 6 & 0,299 & 0,254 & Valid \\
\hline & 7 & 0,633 & 0,254 & Valid \\
\hline & 8 & 0,334 & 0,254 & Valid \\
\hline \multirow{6}{*}{$\begin{array}{c}\text { Kesempatan } \\
\text { (X2) }\end{array}$} & 1 & 0,657 & 0,254 & Valid \\
\hline & 2 & 0,737 & 0,254 & Valid \\
\hline & 3 & 0,812 & 0,254 & Valid \\
\hline & 4 & 0,748 & 0,254 & Valid \\
\hline & 5 & 0,753 & 0,254 & Valid \\
\hline & 6 & 0,732 & 0,254 & Valid \\
\hline \multirow{5}{*}{$\begin{array}{l}\text { Rasionalisasi } \\
\text { (X3) }\end{array}$} & 1 & 0,552 & 0,254 & Valid \\
\hline & 2 & 0,610 & 0,254 & Valid \\
\hline & 3 & 0,778 & 0,254 & Valid \\
\hline & 4 & 0,734 & 0,254 & Valid \\
\hline & 5 & 0,601 & 0,254 & Valid \\
\hline \multirow{7}{*}{$\begin{array}{l}\text { Kapabilitas } \\
\text { (X4) }\end{array}$} & 1 & 0,493 & 0,254 & Valid \\
\hline & 2 & 0,549 & 0,254 & Valid \\
\hline & 3 & 0,558 & 0,254 & Valid \\
\hline & 4 & 0,653 & 0,254 & Valid \\
\hline & 5 & 0,789 & 0,254 & Valid \\
\hline & 6 & 0,775 & 0,254 & Valid \\
\hline & 7 & 0,610 & 0,254 & Valid \\
\hline \multirow{8}{*}{$\begin{array}{c}\text { Budaya Etis } \\
\text { Organisasi } \\
\text { (X5) }\end{array}$} & 1 & 0,369 & 0,254 & Valid \\
\hline & 2 & 0,279 & 0,254 & Valid \\
\hline & 3 & 0,747 & 0,254 & Valid \\
\hline & 4 & 0,746 & 0,254 & Valid \\
\hline & 5 & 0,753 & 0,254 & Valid \\
\hline & 6 & 0,439 & 0,254 & Valid \\
\hline & 7 & 0,702 & 0,254 & Valid \\
\hline & 8 & 0,582 & 0,254 & Valid \\
\hline \multirow{5}{*}{$\begin{array}{c}\text { Fraud } \\
\text { Pengadaan } \\
\text { Barang/Jasa } \\
(\mathrm{Y})\end{array}$} & 1 & 0,440 & 0,254 & Valid \\
\hline & 2 & 0,620 & 0,254 & Valid \\
\hline & 3 & 0,783 & 0,254 & Valid \\
\hline & 4 & 0,513 & 0,254 & Valid \\
\hline & 5 & 0,637 & 0,254 & Valid \\
\hline
\end{tabular}

Pengujian kualitas data dalam penelitian ini dilakukan secara statistik menggunakan uji pearson product-moment coefficient of correlations dengan nilai signifikansi sebesar 5\%. Setiap item dikatakan valid jika nilai $r$ hitung $>r$ tabel. Uji Validitas dapat dilihat pada Tabel 4.1 sebagai berikut:

Tabel 4.1

Hasil Uji Validitas 


\begin{tabular}{|c|c|c|c|c|}
\hline Variabel & Item & r-hitung & r-tabel & Ket \\
\hline \multirow{7}{*}{} & 6 & 0,613 & 0,254 & Valid \\
\cline { 2 - 5 } & 7 & 0,492 & 0,254 & Valid \\
\cline { 2 - 5 } & 8 & 0,565 & 0,254 & Valid \\
\hline
\end{tabular}

Berdasarkan uji validitas tersebut, masing-masing item diperoleh nilai $r_{\text {hitung }}>r_{\text {tabel }}$, yang berarti bahwa seluruh instrumen kuesioner adalah valid.

\section{Hasil Uji Reliabilitas}

Tabel 4.2

Hasil Uji Reliabilitas

\begin{tabular}{|l|c|c|c|}
\hline \multicolumn{1}{|c|}{ Variabel } & $\begin{array}{c}\text { Cronbach } \\
\text { Alpha }\end{array}$ & $\begin{array}{c}\text { Nilai Kritis } \\
\text { Cronbach's } \\
\text { Alpha }\end{array}$ & Ket \\
\hline Tekanan (X1) & 0,620 & 0,600 & Reliabel \\
\hline $\begin{array}{l}\text { Kesempatan } \\
(\text { X2) }\end{array}$ & 0,831 & 0,600 & Reliabel \\
\hline $\begin{array}{l}\text { Rasionalisasi } \\
\text { (X3) }\end{array}$ & 0,667 & 0,600 & Reliabel \\
\hline $\begin{array}{l}\text { Kapabilitas } \\
\text { (X4) }\end{array}$ & 0,745 & 0,600 & Reliabel \\
\hline $\begin{array}{l}\text { Budaya Etis } \\
\text { Organisasi } \\
\text { (X5) }\end{array}$ & 0,739 & 0,600 & Reliabel \\
\hline $\begin{array}{l}\text { Kecurangan } \\
\text { Pengadaan } \\
\text { Barang/Jasa } \\
\text { (Y) }\end{array}$ & 0,725 & 0,600 & Reliabel \\
\hline
\end{tabular}

Berdasarkan Tabel 4.2 di atas, uji reliabilitas menghasilkan nilai Cronbach Alpha untuk setiap variabel yang lebih besar dari 0,60. Dengan demikian dapat disimpulkan bahwa semua variabel adalah reliabel.

\section{Uji Asumsi Klasik}

\section{Hasil Uji Normalitas}

Tabel 4.3

Hasil Uji Normalitas

\begin{tabular}{|c|c|c|}
\hline & $\begin{array}{c}\text { Unstandardized } \\
\text { Residual }\end{array}$ & Keterangan \\
\hline $\begin{array}{c}\text { Asymp. Sig. (2- } \\
\text { tailed) }\end{array}$ & 0,858 & $\begin{array}{c}\text { Data } \\
\text { berdistribusi } \\
\text { normal }\end{array}$ \\
\hline
\end{tabular}

Berdasarkan Tabel 4.3 diatas, nilai unstandardized residual sebesar 0,858 yang berarti lebih besar 0,05 (5\%), maka dapat disimpulkan bahwa data berdistribusi secara normal.

\section{Hasil Uji Multikolinieritas}

Tabel 4.4

Hasil Uji Multikolinieritas

\begin{tabular}{|l|c|c|}
\hline \multirow{2}{*}{\multicolumn{1}{|c|}{ Model }} & \multicolumn{2}{c|}{ Collinearity Statistics } \\
\cline { 2 - 3 } & Tolerance & VIF \\
\hline (constant) & & \\
\hline Tekanan (X1) & 0,786 & 1,272 \\
\hline Kesempatan (X2) & 0,800 & 1,249 \\
\hline Rasionalisasi (X3) & 0,937 & 1,067 \\
\hline Kapabilitas (X4) & 0,673 & 1,485 \\
\hline $\begin{array}{l}\text { Budaya Etis Organisasi } \\
\text { (X5) }\end{array}$ & 0,706 & 1,416 \\
\hline X1.X5 & 0,566 & 1,766 \\
\hline X2.X5 & 0,812 & 1,232 \\
\hline X3.X5 & 0,802 & 1,247 \\
\hline X4.X5 & 0,660 & 1,515 \\
\hline
\end{tabular}

Berdasarkan Tabel 4.4 diatas dapat dilihat bahwa nilai tolerance setiap variabel independen lebih besar dari 0,10 dengan nilai VIF dibawah 10 , hal ini menunjukkan bahwa model regresi bebas dari multikolinieritas.

\section{Hasil Uji Heteroskedastisitas}

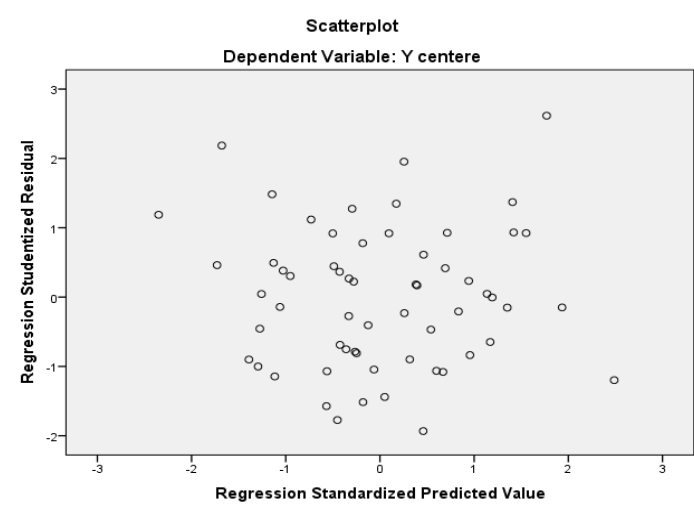

Gambar 4.1 Hasil Uji Heteroskedastisitas

Berdasarkan hasil pengujian heteroskedastisitas, terlihat bahwa tidak ada pola tertentu dan titik-titik menyebar secara merata berada di bawah dan di atas angka 0 pada sumbu Y. Hasil ini menandakan bahwa model regresi yang digunakan tidak terjadi heteroskedastisitas.

\section{Hasil Analisis Regresi Moderasi}

Model penelitian dapat dilihat pada hasil pengolahan data seperti yang terlihat pada bagian output SPSS di Tabel 4.5 dibawah ini: 
Tabel 4.5

Pengaruh Variabel Independen terhadap Variabel Dependen

\begin{tabular}{llrrrrr}
\hline \multirow{2}{*}{ Model } & \multicolumn{2}{c}{ Unstandardized Coefficients } & \multicolumn{3}{c}{ Standardized Coefficients } & \multirow{2}{*}{ Sig. } \\
\cline { 2 - 5 } & \multicolumn{1}{c}{ B } & \multicolumn{2}{c}{ Std. Error } & Beta & & \\
\hline 1 (Constant) & 0,096 & 0,270 & & 0,259 & 2,174 & 0,723 \\
X1 & 0,172 & 0,079 & $-0,104$ & $-0,883$ & 0,382 \\
X2 & $-0,129$ & 0,146 & 0,168 & 1,535 & 0,131 \\
X3 & 0,235 & 0,153 & 0,520 & 4,041 & 0,000 \\
X4 & 0,603 & 0,149 & 0,089 & 0,708 & 0,482 \\
X5 & 0,050 & 0,071 & $-0,171$ & $-1,216$ & 0,230 \\
X1.X5 & $-0,027$ & 0,022 & 0,374 & 3,190 & 0,002 \\
X2.X5 & 0,104 & 0,033 & $-0,365$ & $-3,091$ & 0,003 \\
X3.X5 & $-0,151$ & 0,049 & $-0,069$ & $-0,529$ & 0,599 \\
\hline
\end{tabular}

$\mathrm{R}^{2}=0,442 ; \mathrm{F}=4,398 ;$ Sig. $=0,000$

Berdasarkan output SPSS pada Tabel 4.7, model penelitian dapat dituliskan dalam persamaan dibawah ini:

\section{$Y=0,096+0,172 X 1-0,129 X 2+0,235 X 3+0,603 X 4$ $+0,050 X 5$ - 0,027X1.X5 + 0,104X2.X5 - 0,151X3.X5 - 0,016X4.X5+e}

Hasil persamaan regresi tersebut dapat diketahui bahwa nilai konstanta (a) sebesar 0,096 artinya jika tekanan, kesempatan, rasionalisasi, kapabilitas, dan budaya etis organisasi sebagai pemoderasi dianggap sama dengan nol, maka besarnya nilai kecurangan pengadaan barang/jasa di Pemerintahan Aceh adalah sebesar 0,096 atau $9,6 \%$.

\section{Hasil Uji Koefisien Determinasi $\left(\mathbf{R}^{\mathbf{2}}\right)$}

Berdasarkan Tabel 4.7 nilai $\mathrm{R}^{2}$ sebesar 0,442 atau sebesar $44,2 \%$. Hal tersebut berarti bahwa 44,2\% variabel dependen (fraud pengadaan barang/jasa) dapat dijelaskan oleh keempat variabel independen yang terdiri dari tekanan, kesempatan, rasionalisasi, dan kapabilitas serta satu variabel moderasi yaitu budaya etis organisasi. Sedangkan 55,8\% lainnya dijelaskan oleh variabel lain yang tidak dimasukkan dalam penelitian ini.

\section{Hasil Pengujian Hipotesis}

\section{Hasil Uji Secara Parsial}

Untuk menguji secara parsial pengaruh tekanan, kesempatan, rasionalisasi, kapabilitas, dan budaya etis organisasi sebagai pemoderasi dapat dilihat dengan cara mengambil kesimpulan langsung dari nilai signifikansi masing-masing variabel. Setiap variabel dikatakan berpengaruh, apabila nilai signifikansi nya lebih kecil dari 0,05. Hasil perhitungan diketahui nilai signifikansi untuk masing-masing variabel sebagai berikut:

1) Variabel tekanan memiliki nilai signifikansi 0,034 lebih kecil dari 0,05 (5\%). Hal ini menunjukkan bahwa tekanan berpengaruh terhadap kecurangan (fraud) pengadaan barang/jasa. Dengan demikian, hipotesis pertama $\left(\mathrm{H}_{1}\right)$ diterima.

2) Variabel kesempatan memiliki nilai signifikansi 0,382 lebih besar dari $0,05 \quad(5 \%)$. Hal ini menunjukkan bahwa kesempatan tidak berpengaruh terhadap kecurangan (fraud) pengadaan barang/jasa. Dengan demikian, hipotesis kedua $\left(\mathrm{H}_{2}\right)$ ditolak.

3) Variabel rasionalisasi memiliki nilai signifikansi 0,131 lebih besar dari $0,05 \quad(5 \%)$. Hal ini menunjukkan bahwa rasionalisasi tidak berpengaruh terhadap kecurangan (fraud) pengadaan barang/jasa. Dengan demikian, hipotesis ketiga $\left(\mathrm{H}_{3}\right)$ ditolak.

4) Variabel kapabilitas memiliki nilai signifikansi 0,000 lebih kecil dari 0,05 (5\%). Hal ini menunjukkan bahwa kapabilitas berpengaruh terhadap kecurangan (fraud) pengadaan 
barang/jasa. Dengan demikian, hipotesis keempat $\left(\mathrm{H}_{4}\right)$ diterima.

5) Variabel budaya etis organisasi memiliki nilai signifikansi 0,482 lebih besar dari 0,05 (5\%). Hal ini menunjukkan bahwa budaya etis organisasi tidak berpengaruh terhadap kecurangan (fraud) pengadaan barang/jasa. Dengan demikian, hipotesis kelima $\left(\mathrm{H}_{5}\right)$ ditolak.

6) Hasil analisis pengaruh tekanan terhadap kecurangan (fraud) pengadaan barang/jasa yang dimoderasi oleh budaya etis organisasi memiliki nilai signifikansi 0,230 lebih besar dari 0,05 (5\%), yang berarti budaya etis organisasi tidak dapat memoderasi hubungan antara tekanan dengan kecurangan (fraud) pengadaan barang/jasa, dengan demikian hipotesis keenam $\left(\mathrm{H}_{6}\right)$ ditolak.

7) Hasil analisis pengaruh kesempatan terhadap kecurangan (fraud) pengadaan barang/jasa yang dimoderasi oleh budaya etis organisasi memiliki nilai signifikansi 0,002 lebih kecil dari 0,05 (5\%), yang berarti budaya etis organisasi dapat memoderasi hubungan antara kesempatan dengan kecurangan (fraud) pengadaan barang/jasa. Dengan demikian, hipotesis ketujuh $\left(\mathrm{H}_{7}\right)$ diterima.

8) Hasil analisis pengaruh rasionalisasi terhadap kecurangan (fraud) pengadaan barang/jasa yang dimoderasi oleh budaya etis organisasi memiliki nilai signifikansi 0,003 lebih kecil dari 0,05 (5\%), yang berarti budaya etis organisasi dapat memoderasi hubungan antara rasionalisasi dengan kecurangan (fraud) pengadaan barang/jasa. Dengan demikian, hipotesis kedelapan $\left(\mathrm{H}_{8}\right)$ diterima.

9) Hasil analisis pengaruh kapabilitas terhadap kecurangan (fraud) pengadaan barang/jasa yang dimoderasi oleh budaya etis organisasi memiliki nilai signifikansi 0,599 lebih besar dari 0,05 (5\%), yang berarti budaya etis organisasi tidak dapat memoderasi hubungan antara kapabilitas dengan kecurangan (fraud) pengadaan barang/jasa. Dengan demikian, hipotesis kesembilan $\left(\mathrm{H}_{9}\right)$ ditolak.

\section{Pembahasan}

\section{Pengaruh Tekanan (Pressure) Terhadap Kecurangan Pada Pengadaan Barang/Jasa}

Berdasarkan hasil pengujian hipotesis yang telah disajikan sebelumnya dapat disimpulkan bahwa tekanan berpengaruh secara positif terhadap kecurangan pengadaan barang/jasa. Artinya apabila seseorang mengalami tekanan yang besar akan meningkatkan terjadinya kecurangan pengadaan barang/jasa.

Tekanan adalah motivasi yang timbul dari individu pegawai untuk melakukan perbuatan curang dan menyimpang disebabkan karena adanya tekanan. Berbagai tekanan yang terjadi baik itu tekanan finansial maupun non-finansial, mengakibatkan seseorang mengalami kesulitan dan terjebak pada situasi yang sulit. Sehingga dapat memotivasi seseorang untuk menghalalkan segala cara agar terbebas dari situasi sulit tersebut.

Hasil penelitian ini konsisten dengan penelitian (Muhammad \& Ridwan, 2017) yang memproksikan tekanan dengan kompensasi pegawai. Masalah keuangan pegawai juga erat kaitannya dengan jumlah kompensasi yang diberikan atasan. Kompensasi pegawai memiliki pengaruh negatif terhadap kecurangan, apabila kompensasi yang diterima pegawai semakin besar jumlah nominalnya maka semakin kecil kemungkinan untuk melakukan kecurangan. Mengapa demikian, karena apabila pegawai menerima kompensasi dalam jumlah yang besar, kompensasi tersebut dapat mencukupi kebutuhan hidupnya. Sehingga motivasinya untuk berbuat kecurangan semakin berkurang.

Hasil penelitian ini tidak mendukung penelitian yang dilakukan oleh Arifianti et al., (2015) yang menyatakan bahwa tekanan tidak berpengaruh terhadap kecurangan pengadaan barang/jasa. Tekanan diproksikan dengan kesesuaian kompensasi. Hasilnya ialah ada dan tidak adanya tambahan kompensasi tidak berpengaruh terhadap kecurangan yang terjadi, karena para pejabat pengadaan bekerja tidak semata-semata untuk mendapatkan keuntungan dari kompensasi saja, melainkan keuntungan jangka panjang seperti meningkatkan kemampuan, pengetahuan, keahlian, dan memperbanyak pengalaman di bidang pengadaan barang/jasa. 


\section{Pengaruh Kesempatan (Opportunity) Terhadap Kecurangan Pada Pengadaan Barang/Jasa}

Berdasarkan hasil pengujian hipotesis yang telah disajikan sebelumnya dapat disimpulkan bahwa kesempatan tidak berpengaruh terhadap kecurangan pengadaan barang/jasa. Tidak adanya pengaruh antara kesempatan dengan kecurangan pengadaan barang/jasa disebabkan karena sistem pengendalian yang diterapkan di suatu organisasi sudah efektif, sehingga sulit bagi para pelaku untuk melakukan tindakan kecurangan.

Selain itu, semakin bagus sistem pengendalian internalnya maka kemungkinan terdeteksi kecurangan akan lebih mudah dan cepat. Hal tersebut yang mengakibatkan sedikitnya kesempatan atau peluang yang tersedia. Ditambah lagi dengan adanya pemisahan tugas dan otorisasi, sehingga tidak semua orang dapat terlibat dalam kegiatan pengadaan barang/jasa kecuali pihak yang memang bertanggungjawab di bidang tersebut.

Hasil penelitian ini sejalan dengan penelitian dari Adi et al., (2016). Dalam penelitian Adi et al., (2016) menyatakan bahwa pegawai instansi yang menjadi objek penelitiannya sudah mematuhi prosedur yang ditetapkan serta tugas dan tanggungjawab masing-masing pegawai sudah sesuai dengan alur sistem yang berlaku. Hanya saja pada aktivitas operasional untuk menilai pelaksanaan pengendalian internal tidak dapat dipantau dan dievaluasi secara kontinuitas. Hal inilah yang mengakibatkan terbukanya kesempatan bagi pegawai untuk melakukan perbuatan curang dan menyimpang.

Hasil penelitian tidak sejalan dengan penelitian Zahara (2017) yang menemukan adanya pengaruh positif kesempatan terhadap kecurangan (fraud) pengadaan barang/jasa. Adanya pengaruh kesempatan terhadap kecurangan sesuai dengan teori segitiga kecurangan, yang mana kesempatan menjadi salah satu faktor yang dapat memotivasi seseorang untuk berbuat curang. Motivasi tersebut meningkat ketika pemberian sanksi lemah dan resiko tertangkap rendah, sehingga apabila motivasi untuk berbuat curang tinggi maka intensitas kecurangan yang terjadi juga meningkat.

Sementara itu, penelitian Albar dan Fauziah (2018) mendapatkan hasil penelitian yang menyatakan adanya pengaruh negatif kesempatan terhadap kecurangan. Semakin baik pengendalian internal yang diimplementasikan pada suatu instansi pemerintah, maka semakin menurun tingkat kecurangan yang terjadi, dalam hal ini objek penelitian dilakukan di SKPD Pemerintahan Kota Lhokseumawe.

\section{Pengaruh Rasionalisasi (Rationalization) Terhadap Kecurangan Pada Pengadaan Barang/Jasa}

Berdasarkan hasil pengujian hipotesis yang telah disajikan sebelumnya dapat disimpulkan bahwa rasionalisasi tidak berpengaruh terhadap kecurangan pengadaan barang/jasa. Rasionalisasi diartikan sebagai bentuk pembenaran diri terhadap apa yang telah dilakukan pelaku kecurangan dan menganggap bahwa tindakannya tidak menyimpang. Sesuai dengan hasil penelitian ini, tidak adanya pengaruh antara rasionalisasi dengan kecurangan pengadaan barang/jasa dikarenakan tidak semua individu melakukan pembenaran diri (rasionalisasi) terhadap perbuatannya.

Setiap individu yang menjungjung tinggi nilainilai integritas menyadari bahwa perilaku kecurangan adalah perilaku yang ilegal sehingga mereka akan menghindari perbuatan tersebut. Selain itu, bagi individu yang memiliki tingkat spritiual tinggi artinya taat pada keyakinan akan menjauhi setiap perbuatan yang menyimpang dan tidak sesuai dengan ajaran keyakinannya. Hal inilah yang menyebabkan rasionalisasi tidak berpengaruh terhadap kecurangan pengadaan barang/jasa.

Hasil penelitian ini didukung oleh penelitian sebelumnya yang dilakukan oleh Susandra dan Hartina (2017), tentunya hasil ini tidak sesuai dengan teori fraud triangle, karena rasionalisasi merupakan bagian dari penyebab yang dapat memicu seseorang untuk melakukan perbuatan curang. Susandra dan Hartina (2017) dalam penelitiannya menyatakan bahwa, ketika individu mengedepankan integritas dan moralitas dalam bersikap di suatu instansi, maka setiap tindakan yang dilakukan merupakan bagian dari perilaku etis dan tidak menyimpang. Hal inilah yang menyebabkan seseorang enggan untuk melakukan rasionalisasi (pembenaran diri) sehingga rasionalisasi tidak dapat memicu terjadinya kecurangan.

Hasil penelitian ini tidak sejalan dengan penelitian Purwanto et al., (2017) yang memperoleh hasil bahwa rasionalisasi berpengaruh positif terhadap kecurangan (fraud) pengadaan barang/jasa. Hubungan positif tersebut, menunjukkan bahwa semakin banyak 
rasionalisasi dilakukan oleh pelaku, maka semakin besar jumlah kecurangan yang akan terjadi. Mengapa demikian, alasan utamanya ialah beranggapan bahwa keuntungan yang didapatkan lebih besar dari resiko terdeteksi.

\section{Pengaruh Kapabilitas (Capability) Terhadap Kecurangan Pada Pengadaan Barang/Jasa}

Berdasarkan hasil pengujian hipotesis yang telah disajikan sebelumnya dapat disimpulkan bahwa kapabilitas berpengaruh positif terhadap kecurangan pengadaan barang/jasa. Berhasil atau tidak berhasilnya kecurangan ditentukan oleh kapabilitas atau kemampuan pelaku dalam melakukan kecurangan, ada dua kapabilitas yang harus dimiliki pelaku untuk mensukseskan tindakan kecurangannya, diantaranya jabatan dan kepintaran.

Tingginya jabatan seseorang dalam suatu instansi akan memberikan kemudahan baginya untuk melakukan kecurangan dan risiko terdeteksi juga semakin kecil. Kemudian kepintaran pelaku dalam menganalisa sistem pengendalian internal, dapat memudahkan pelaku untuk mengetahui bagian mana dari sistem pengendalian internal yang dapat disalahgunakan. Oleh sebab itu, pada penelitian ini memberikan hasil bahwa kesempatan berpengaruh positif terhadap kecurangan pengadaan barang/jasa, semakin bagus kapabilitas seseorang maka semakin besar kecurangan yang terjadi.

Sesuai dengan teori kapabilitas Wolfe \& Hermanson (2004) tingkat kapabilitas seseorang sangat erat kaitannya dengan akibat yang ditimbulkan dari kecurangan. Mengapa demikian, semakin tinggi kapabilitas seseorang dalam menempati posisi jabatan di instansi/perusahaan, maka semakin besar jumlah nominal kerugian yang ditanggung perusahaan.

Hasil penelitian ini konsisten dengan penelitian Irphani (2017), menyatakan bahwa kapabilitas atau kompetensi yang dimiliki seseorang baik itu berupa jabatan dan kewenangan, semakin tinggi jabatan seseorang dalam suatu instansi maka semakin besar pula kecenderungan untuk melakukan tindakan kecurangan.

Sementara itu, Fazini dan Suparno (2018) dalam penelitiannya memperoleh hasil bahwa kapabilitas yang diukur dengan kapasitas sumber daya manusia berpengaruh negatif terhadap kecurangan akuntansi. Kapasitas sumber daya manusia dapat dikategorikan baik, apabila dalam menjalankan tugas fungsi dan tanggungjawab dibekali dengan pendidikan, pelatihan dan pengalaman yang memadai. Sehingga dapat meningkatkan kualitas hasil pekerjaannya, dengan begitu dapat terhindar dari kesalahan akuntansi yang merujuk kepada kecurangan, meskipun dilakukan tanpa ada unsur kesengajaan. Oleh karena itu, semakin berkualitas kapasitas sumber daya manusia, semakin berkurang tingkat kecurangan akuntansi yang terjadi.

Hasil penelitian ini tidak konsisten dengan penelitian Siregar dan Hamdani (2018) menjelaskan bahwa tinggi atau rendahnya kapabilitas seseorang dalam lingkungan kerja, seperti posisi atau jabatan tidak akan berpengaruh terhadap kecurangan yang terjadi, karena apabila seseorang menjunjung tinggi sikap integritas dan moralitas, setinggi apapun jabatannya pasti tidak akan menyalahkan kewenangannya. Dengan demikian, kapabilitas tidak berpengaruh terhadap kecurangan.

\section{Pengaruh Budaya Etis Organisasi Terhadap Kecurangan Pada Pengadaan Barang/Jasa}

Hasil penelitian menunjukkan bahwa budaya etis organisasi tidak berpengaruh terhadap kecurangan pengadaan barang/jasa. Tidak adanya pengaruh antara budaya etis organisasi dengan kecurangan pengadaan barang/jasa disebabkan karena sudah diterapkannya budaya etis organisasi yang sesuai dengan nilai dan norma. Apabila disuatu organisasi sudah menerapkan budaya etis didalamnya maka seluruh pegawai dan juga pimpinan selalu berusaha mencapai tujuan organisasi dengan menjunjung tinggi nilai-nilai etis. Sehingga dalam lingkungan kerja mereka selalu senantiasa untuk meningkatkan produktivitasnya tanpa menghalalkan segala cara.

Hasil ini didukung dengan penelitian Sugiarto (2018), menyatakan bahwa tingkat keetisan suatu budaya berbeda-beda tergantung dari masing-masing organisasi. Budaya yang dikatakan etis disuatu organisasi belum tentu etis pada organisasi lain, sehingga budaya etis organisasi tidak memiliki pengaruh yang signifikan terhadap kecurangan di instansi pemerintahan.

Hasil penelitian ini tidak sejalan dengan penelitian Fachrunisa (2015) yang memperoleh hasil budaya etis organisasi berpengaruh positif terhadap kecurangan pengadaan barang/jasa. Ketika budaya organisasi sudah sesuai dengan nilai dan norma, secara 
tidak langsung akan membentuk rasa ikut memiliki oleh masing-masing pegawai dalam instansi pemerintahan. Rasa ikut memiliki tersebut yang dapat mendorong seseorang untuk melakukan tindakan kecurangan, karena ia menganggap bahwa organisasi tempatnya bekerja adalah miliknya. Sehingga, dapat disimpulkan ketika semakin baik budaya etis di suatu organisasi maka semakin besar rasa memiliki terhadap organisasi tersebut, inilah yang dapat menyebabkan tendensi kecurangan semakin sering terjadi.

\section{Pengaruh Budaya Etis Organisasi Terhadap Hubungan Antara Tekanan Dengan Kecurangan Pengadaan Barang/Jasa}

Hipotesis keenam yang diuji dengan menggunakan uji interaksi memberikan hasil bahwa budaya etis organisasi tidak berpengaruh atau tidak dapat memoderasi hubungan antara tekanan dengan kecurangan pengadaan barang/jasa. Ketidaksanggupan budaya etis organisasi untuk memoderasi hubungan tersebut ialah karena setiap orang memiliki tekanan yang berbeda-beda yang sifatnya tidak sama, yang mana tekanan tersebut tidak dapat dikendalikan dan diatasi oleh budaya etis organisasi. Sehingga, budaya etis organisasi tidak dapat memberikan peranan untuk memperkuat atau bahkan memperlemah hubungan antara tekanan dengan kecurangan pengadaan barang/jasa.

\section{Pengaruh Budaya Etis Organisasi Terhadap Hubungan Antara Kesempatan Dengan Kecurangan Pengadaan Barang/Jasa}

Penelitian ini menggunakan budaya etis organisasi sebagai pemoderasi, hasil yang diperoleh ialah budaya etis organisasi dapat memoderasi hubungan antara kesempatan dengan kecurangan pengadaan barang/jasa. Budaya etis organisasi sebagai pemoderasi memiliki kaitan dengan kesempatan karena kedua hal tersebut sama-sama ditentukan oleh pihak eksternal yaitu organisasi. Kesempatan dapat dibatasi dengan adanya penerapan sistem pengendalian internal sehingga menurunkan kecurangan pengadaan barang/jasa, sedangkan budaya etis organisasi menanamkan nilai-nilai etika kepada seluruh pegawai dan pimpinan untuk bekerja sesuai dengan kode etik sehingga kecurangan tidak terjadi. Karena kesempatan dan budaya etis organisasi keduanya ditentukan oleh organisasi itu sendiri, dengan demikian dapat disimpulkan bahwa budaya etis organisasi dapat memoderasi hubungan kesempatan dengan kecurangan pengadaan barang/jasa.

\section{Pengaruh Budaya Etis Organisasi Terhadap Hubungan Antara Rasionalisasi Dengan Kecurangan Pengadaan Barang/Jasa}

Hasil pengujian hipotesis kedelapan mengenai hubungan antara rasionalisasi dengan kecurangan pengadaan barang/jasa, yang mana didalam hubungan tersebut dapat dimoderasi oleh budaya etis organisasi. Meskipun budaya etis organisasi dan rasionalisasi berasal dari sumber yang berbeda, dalam arti budaya etis organisasi bersumber dari ekternal dan rasionalisasi dari internal dalam pengujian ini budaya etis organisasi dapat menjadi pemoderasi.

Hal ini dikarenakan apabila seseorang berpegang teguh pada nilai-nilai etika, yang mana nilai-nilai tersebut sejalan dengan budaya etis di organisasinya maka orang tersebut merasa enggan untuk melakukan pembenaran (rasionalisasi) diri atas apa yang telah dilakukannya. Namun sebaliknya, apabila kedua nilai tersebut sama-sama menyalahi aturan etika maka juga dapat mendorong seseorang untuk melakukan rasionalisasi terhadap tindakannya.

\section{Pengaruh Budaya Etis Organisasi Terhadap Hubungan Antara Kapabilitas Dengan Kecurangan Pengadaan Barang/Jasa}

Hasil pengujian menunjukkan bahwa hubungan antara kapabilitas terhadap kecurangan pengadaan barang/jasa tidak dapat dimoderasi oleh budaya etis organisasi. Hal tersebut dikarenakan kapabilitas merupakan faktor internal yang timbul dari dalam diri seseorang yang sulit dikendalikan oleh pihak lain kecuali individu itu sendiri (Rasha \& Andrew, 2012) (Wolfe \& Hermanson, 2004). Sedangkan budaya etis organisasi adalah budaya yang diciptakan dan dikembangkan oleh pihak eksternal seperti organisasi di lingkungan kerja (Griffin, 2013). Kedua perbedaan tersebut saling berlainan sehingga budaya etis organisasi tidak bisa menjadi pemoderasi untuk hubungan tersebut.

\section{Kesimpulan, Keterbatasan Dan Saran Kesimpulan}

Berdasarkan hasil pengujian hipotesis diperoleh kesimpulan sebagai berikut: 
1) Tekanan (pressure) berpengaruh terhadap kecurangan pada pengadaan barang/jasa di Pemerintahan Aceh.

2) Kesempatan (opportunity) tidak berpengaruh terhadap kecurangan pada pengadaan barang/jasa di Pemerintahan Aceh.

3) Rasionalisasi (rationalization) tidak berpengaruh terhadap kecurangan pada pengadaan barang/jasa di Pemerintahan Aceh.

4) Kapabilitas (capability) berpengaruh terhadap kecurangan pada pengadaan barang/jasa di Pemerintahan Aceh.

5) Budaya etis organisasi tidak berpengaruh terhadap kecurangan pada pengadaan barang/jasa di Pemerintahan Aceh.

6) Budaya etis organisasi tidak berpengaruh (tidak dapat memoderasi) hubungan tekanan dengan kecurangan pengadaan barang/jasa di Pemerintahan Aceh.

7) Budaya etis organisasi berpengaruh (dapat memoderasi) hubungan kesempatan dengan kecurangan pengadaan barang/jasa di Pemerintahan Aceh.

8) Budaya etis organisasi berpengaruh (dapat memoderasi) hubungan rasionalisasi dengan kecurangan pengadaan barang/jasa di Pemerintahan Aceh.

9) Budaya etis organisasi tidak berpengaruh (tidak dapat memoderasi) hubungan kapabilitas dengan kecurangan pengadaan barang/jasa di Pemerintahan Aceh.

\section{Keterbatasan}

Keterbatasan yang dimiliki oleh penelitian ini adalah sebagai berikut:

1) Penelitian ini hanya terbatas pada persepsi jawaban responden, belum mencakup pengukuran yang memadai untuk mendeteksi adanya kecurangan di sektor pengadaan barang/jasa. Hal ini dapat menimbulkan masalah jika persepsi responden berbeda dengan keadaan yang sebenarnya.

2) Nilai koefisien determinasi $\left(R^{2}\right)$ yang masih rendah, artinya masih banyak variabel bebas lainnya yang dapat mempengaruhi kecurangan pengadaan barang/jasa yang tidak dimasukkan keadalam penelitian ini.
Untuk menambah referensi penelitian selanjutnya, ada beberapa saran yang dikemukakan, diantaranya:

1) Diharapkan untuk penelitian selanjutnya selain menggunakan alat pengumpulan data berupa kuesioner, tetapi juga menggunakan pengukuran yang memadai. Sehingga kecurangan dapat dideteksi dengan baik dan akurat.

2) Diharapkan penelitian selanjutnya dapat menambah variabel bebas lain yang diduga dapat memengaruhi audit report lag yang tidak diikutsertakan dalam penelitian ini.

\section{Daftar Pustaka}

Adi, M. Riski K., Komala A., \& Arum A. (2016). Analisis Faktor-Faktor Penentu Kecurangan (Fraud) Pada Sektor Pemerintahan (Studi Kasus Pada Dinas Pendapatan Pengelolaan Keuangan dan Aset Daerah Kota Pekalongan). Jurnal Litbang Kota Pekalongan, 10, 1-10.

Albar, T. Meurah., \& Fauziah A. Fitri. (2018). Pengaruh Komitmen Organisasi, Etika Organisasi, Keadilan Kompensasi, dan Sistem Pengendalian Internal Terhadap Fraud (Studi Empiris Pada SKPD Pemerintah Kota Lhokseumawe). Jurnal Ilmiah Mahasiswa Ekonomi Akuntansi (JIMEKA), 3(3), 527-537.

Albrecht, Chad., Mary-Jo K., \& Steve A. (2012). Fraud Examination. South Western: Cengage Learning. E-Book.

Annisya, M., Lindrianasari., \& Yuztitya, A. (2016). Pendeteksian Kecurangan Laporan Keuangan Menggunakan Fraud Diamond. Jurnal Bisnis dan Ekonomi, 23(1), 72-89.

Apriadi, Rangga Nuh. (2014). Determinan Terjadinya Fraud di Institusi Pemerintahan. Skripsi. Malang: Universitas Brawijaya.

Arifianti, R., Budi S., \& Lilik H. (2015). Perspektif Triangle Fraud Theory dalam Pengadaan Barang/Jasa di Pemerintahan Provinsi NTB. Jurnal InFestasi, 11(2), 195-213.

Aulad, A., N. Hidayati., \& Junaidi. (2018). Pengaruh Partisipasi Penyusunan Anggaran Terhadap Kinerja Aparat Pemerintah Daerah: Budaya Organisasi dan Komitmen Organisasi Sebagai Variabel Moderating (Studi Empiris Pda SKPD Kota Malang). E-JRA Fakultas Ekonomi dan Bisnis Universitas Islam Malang, 7(7), 111-120. 
Cressey, D. R. (1953). Other People's Money: A Study in the Social Psychology of Embezzlement. USA: The Free Press.

Dewi, Putu P., I Wayan R., \& N. K. Rasmini. (2015). Pengaruh Pengalaman, Orientasi Etika, Komitmen dan Budaya Etis Organisasi Pada Sensitivitas Etika Auditor Badan Pengawasan Keuangan dan Pembangunan Perwakilan Provinsi Bali. E-Jurnal Ekonomi dan Bisnis Universitas Udayana, 4(11), 841-865.

Fachrunisa, Aisah. (2015). Pengaruh Keefektifan Pengendalian Internal, Keadilan Distributif, Keadilan Prosedural, dan Budaya Etis Organisasi Terhadap Kecenderungan Kecurangan (Fraud) Akuntansi (Studi Empiris Pada SKPD Kabupaten Kampar). Journal Online Mahasiswa (JOM) FEKON, 2(2), 1-15.

Farida, Siti Nur. (2017). Analisis Pengaruh Fraud Diamond, Personal Attitude dan Effectiveness of Internal Control Terhadap Tendensi Kecurangan Karyawan Pada Dealer Otomotif di Wilayah Jombang. Skripsi. Malang: UIN Maulana Malik Ibarhim.

Fazini, Harum N., \& Suparno. (2018). Pengaruh Sumber Daya Manusia dan Pengendalian Internal Terhadap Kecurangan Akuntansi Studi Pada PT Pegadaian (Persero) di Kota Banda Aceh. Jurnal Ilmiah Mahasiswa Ekonomi Akuntansi (JIMEKA), 3(4), 625-637.

Griffin, Moorhead (2013). Perilaku Organisasi. Jakarta: Salemba Empat.

Hunt, S. D., \& S. J. Vite. (1986). "A General Theory of Marketing Ethics". Journal of Macromarketing Spring, 5-16.

Irphani, Adi. (2017). Pengaruh Tekanan, Keefektifan Sistem Pengendalian Internal, Perilaku Tidak Etis, dan Jabatan dalam Pengelola Keuangan Terhadap Fraud (Studi Pada Satuan Kerja Perangkat Daerah Kota Metro). Tesis. Bandar Lampung: Universitas Lampung.

Kinicki, Angelo., \& Robert Kreitner. (2003). Perilaku Organisasi (Organizational Behaviour). Jakarta: Salemba Empat.

Komisi Pemberantasan Korupsi. (2018). Melalui (https://www.kpk.go.id). Diakses pada tanggal 1 November 2018.

Korupsi Pengadaan Barang dan Jasa. (2017). melalui (https://www.theindonesianinstitute.com).
Diakses pada tanggal 3 Oktober 2018.

Lailiyah, Afidatul. (2016). Variabel-variabel yang Berpengaruh Terhadap Kecurangan (Fraud) di Sektor Pemerintahan: Persepsi Pegawai Bidang Keuangan di Lingkungan Pemerintah Kabupaten Situbundo. Skripsi. Jember: Unversitas Jember.

Lailiyah, Afidatul. (2016). Variabel-variabel yang Berpengaruh Terhadap Kecurangan (Fraud) di Sektor Pemerintahan: Persepsi Pegawai Bidang Keuangan di Lingkungan Pemerintah Kabupaten Situbundo. Skripsi. Jember: Unversitas Jember.

Marliani, M., \& Y. Jogi. (2015). Persepsi Pengaruh Fraud Triangle Terhadap Pencurian Kas. Business Accounting Review, 3(2), 21-30.

Molida, Resti. (2011). Pengaruh Financial Stability, Personal Financial Need, dan Ineffective Monitoring Pada Financial Statement Fraud dalam Perspektif Fraud Triangle. Skripsi. Semarang: Universitas Diponegoro.

Muhammad, Ryan., \& Ridwan Ibrahim. (2017). Pengaruh Kesesuaian Kompensasi, Penerapan Sistem Informasi Akuntansi, dan Efektivitas Pengendalian Internal Terhadap Kecurangan Akuntansi Studi Pada Bank Perkreditan Rakyat (BPR) di Kota Banda Aceh. Jurnal Ilmiah Mahasiswa Ekonomi Akuntansi (JIMEKA), 2(4), 136-145.

Mustikasari, Dhermawati Putri. (2013). Persepsi Pegawai Dinas Se-Kabupaten Batang Tentang Faktor-Faktor yang Mempengaruhi Kecurangan Fraud. Skripsi. Semarang: Universitas Negeri Semarang.

Nugroho, R. S., Wanto, A. H., \& Trisnawati. (2015). Pengaruh Implementasi Sistem Pengadaan Secara Elektronik (E-Procurement) Terhadap Fraud Pengadaan Barang/Jasa Pemerintah (Studi Pada Satuan Kerja Perangkat Daerah Kabupaten Magetan). Jurnal Administrasi Publik (JAP), 3(1), 1905-1911.

Nurfarida, Lia. (2011). Pengaruh Budaya Etis Organisasi dan Orientasi Etika Terhadap Komitmen Organisasi dan Sensitivitas Etika Auditor (Studi pada Aparatur Inspektorat Kabupaten Bogor). Skripsi. Jakarta: UIN Syarif Hidayatullah Jakarta.

Pamungkas, Ridwan Putra. (2018). Deteksi Kecurangan Pelaporan Keuangan Dengan Teori Fraud Diamond Pada Laporan Keuangan 
Pemerintah Daerah. Skripsi. Lampung: Universitas Lampung.

Purwanto, E., Mulyadi, \& Choirul, A (2017). Kajian Konsep Diamond Fraud Theory dalam Menunjang Efektivitas Pengadaan Barang/Jasa. Jurnal Manajemen Indonesia, 17(3), 149-162.

Ratmono, Dwi., Yuvita A. D., \& Agus P. (2014). Dapatkah Teori Fraud Triangle Menjelaskan Kecurangan dalam Laporan Keuangan. Skripsi. Semarang: Universitas Diponegoro.

Ristianingsih, Ika. (2017). Telaah Konsep Fraud Diamond Theory dalam Mendeteksi Perilaku Fraud di Perguruan Tinggi. Prosiding Seminar Nasional dan Call For Paper Ekonomi dan Bisnis. Jember 27-28 Oktober 2017, 128-139.

Sawitri, Peni. (2011). Interaksi Budaya Organisasi dengan Sistem Pengendalian Manajemen Terhadap Kinerja Unit Bisnis Industri Manufaktur dan Jasa. Jurnal Manajemen dan Kewirausahaan, 13(2), 151-161.

Sihombing., K. S., \& Rahardjo, S. N. (2014). Analisis Fraud Diamond Dalam Mendeteksi Financial Statement Fraud: Studi Empiris Pada Perusahaan Manufaktur yang Terdaftar Di Bursa Efek Indonesia (BEI) tahun 2010-2012. Jurnal akuntansi, 3(2), 1-12.

Simbolon, David K. (2017). Analisis Faktor-faktor yang Mempengaruhi Fraud di Lingkungan Instansi Pemerintahan Kabupaten Dairi. Tesis. Medan: Universitas Sumatera Utara.

Siregar, M. Ichsan., \& Mufid H. (2018). Pengaruh Kesesuaian Kompensasi, Keefektifan Sistem Pengendalian Internal, Budaya Organisasi, dan Kompetensi Terhadap Fraud (Studi Pada Satuan Kerja Vertikal Kementerian Keuangan Provinsi Lampung). Jurnal Ekonomi Global Masa Kini Mandiri, 9(1), 30-37.

Skousen, C. J., Kevin R. S., \& Charlotte J. W. (2008). Detecting And Predicting Financial Statement Fraud: The Effectiveness Of The Fraud Traingle And SAS No. 99. Melaui (http://ssrn.com). Diakses pada tanggal 28 Februari 2019.

Sugiarto, Rudy. (2018). Analisis Pengaruh Kesesuaian Kompensasi, Komitmen Organisasi, Budaya Etis Organisasi, Keefektifan Pengendalian Internal, dan Kompetensi Terhadap Fraud di Sektor Pemerintah Kabupaten Klaten (Studi Pada Dinas Pemerintahan Kabupaten Klaten). Skripsi.
Yogyakarta: STIE Widya Wiwaha.

Susandra, F., \& S. Hartina. (2017). Analisis Faktorfaktor yang Mempengaruhi Kecenderungan Fraud pada Satuan Kerja Perangkat Daerah (SKPD) di Kota Bogor. Jurnal Akunida, 3(2), 35-55.

Tuanakotta, Theodorus M. (2013). Audit Berbasis ISA (International Standards on Auditing). Jakarta: Salemba Empat.

Widarti. (2015). Pengaruh Fraud Triangle Terhadap Deteksi Kecurangan Laporan Keuangan Pada Perusahaan Manufaktur Yang Terdaftar di Bursa Efek Indonesia (BEI). Jurnal Manajemen dan Bisnis Sriwijaya, 13(2).

Wolfe, D. T., \& Hermanson, D. R. (2004). The Fraud Diamond: Considering The Four Elements of Fraud. The CPA Journal, 74(12), 38.

Yeni. (2011). Persepsi Mahasiswa Akuntansi Universitas Bina Nusantara Terhadap Fraudulent Financial Statement. Tesis. Jakarta: Universitas Bina Nusantara.

Zahara, Ami. (2017). Pengaruh Tekanan, Kesempatan, dan Rasionalisasi Terhadap Tindakan Kecurangan (Fraud) (Survei pada Narapidana Tipikor di Lembaga Pemasyarakatan Kelas II A Kota Pekanbaru). Skripsi. Sumatera Barat: Universitas Negeri Padang. 